\title{
Clinical, Histological and Dermoscopic Findings in Familial Cylindromatosis: a Report of Two Cases
}

\author{
Danica TIODOROVIĆ ${ }^{1,2}$, Miljan KRSTIĆ ${ }^{2,3}$ \\ ${ }^{1}$ Clinic of Skin and Venereal Diseases, Clinical Center of Niš, Serbia \\ ${ }^{2}$ Faculty of Medicine, University of Niš, Serbia \\ ${ }^{3}$ Institute of Pathology, Clinical Center of Niš, Serbia \\ *Correspondence: Danica Tiodorović, E-mail: danica.dr@gmail.com
}

UDC 616.594.1-006.03/.04-091.8

\section{DE GRUYTER OPEN}

\begin{abstract}
Cylindromas are benign appendage tumors mainly found on the scalp, but they can occur on any hair-bearing skin. Mutations in the cylindromatosis (CYLD) gene, a tumor suppressor gene located on chromosome 16q12-13, are responsible for multiple cylindromas, which are usually inherited in an autosomal dominant way, as in familial cylindromatosis and BrookeSpiegler syndrome. The latter is characterized by the presence of multiple cylindromas, multiple trichoepitheliomas and spiradenomas. Based on genetic studies and the identification of heterozygous mutations in the same CYLD gene in familial cylindromatosis, multiple familial trichoepitheliomas, and the Brooke-Spiegler syndrome, it is suggested that these three conditions have the same genetic basis and are phenotypic expressions of the same disease. The diagnosis of each of the tree conditions is based on the dominant tumor type: cylindroma in familiar cyindromas, trichoepithelioma in multiple familial trichoepitheliomas, or a variety of skin appendage tumors including cylindromas, spiradenomas and trichoepitheliomas in Brooke-Spiegler syndrome. The onset of the disease is usually in the early adulthood, but may also occur in childhood or adolescence.

We report on two sisters, 37 and 43 years of age, with multiple cylindromas on the face and the scalp. Both patients reported that their mother also had multiple tumors on her head. Dermoscopy revealed arborizing vessels on a white-ivory or pink background, resembling dermoscopic features of basal cell carcinoma, though histopathological analysis revealed cylindroma.

In conclusion, in this study we report two cases of a very rare familial cylindromatosis, presenting with multiple benign cylidromas with dermoscopic features of basal cell carcinoma. All patients with multiple cylindromas in familial cylindromatosis should be counseled about increased risk for developing further tumors. Systemic and multidisciplinary approach with follow up is strongly recommended.
\end{abstract}

\section{Key words}

Neoplasms, Multiple Primary; Dermoscopy; Skin Neoplasms; Scalp; Neoplastic Syndromes, Hereditary; Case Reports; Mutation; Histological Techniques

amilial cylindromatosis is a rare hereditary
disorder characterized by the presence of multiple cylindromas predominantly located on the scalp, face and neck (1). The onset of the disease is usually in the early adulthood, but may also occur in childhood or adolescence. Clinically, cylindromas are benign, rare, skin appendage tumors mainly found on the scalp, but they can occur on any hair-bearing skin. The lesions classically present as painless, smooth pink nodules, which may be either solitary or clustered together. They are slow-growing and different in size, which ranges from a few millimeters to over six centimeters. Mutations in the cylindromatosis (CYLD) gene, a tumor suppressorgenelocated on chromosome 16q1213 , are responsible for multiple cylindromas, which are usually inherited in autosomal dominant fashion, as in familial cylindromatosis and Brooke-Spiegler syndrome (BSS) $(1,2,3)$. The latter, also inherited 
by autosomal dominant transmission, represents a rare hereditary disorder characterized by the presence of multiple cylindromas, multiple trichoepitheliomas and spiradenomas. Based on genetic studies and the identification of more than heterozygous mutations in the same CYLD gene in familial cylindromatosis, multiple familial trichoepitheliomas and the BrookeSpiegler syndrome, it is suggested that these three conditions have the same genetic basis and are phenotypic expressions of the same disease, now viewed as allelic variants with overlapping phenotypes $(2,4,5)$.

The diagnosis of each of the three conditions is based on the dominant tumor type: cylindroma in familiar cyindromatosis, trichoepithelioma in multiple familial trichoepitheliomas, or a variety of skin appendage tumors including cylindromas, spiradenomas and trichoepitheliomas in BSS. From the aspect of clinical features, in terms of prognostic information for patients, this classification is not valuable, and therefore the term CYLD cutaneous

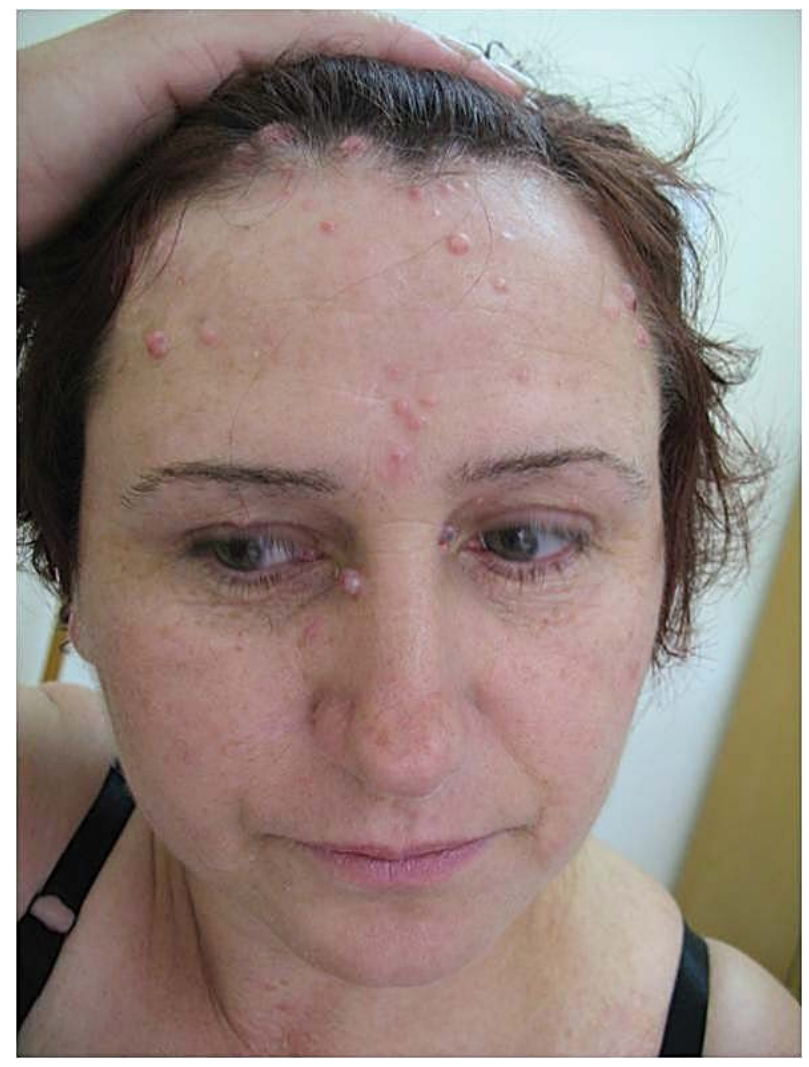

Figure 1. Multiple pinkish nodular lesions on the scalp and face

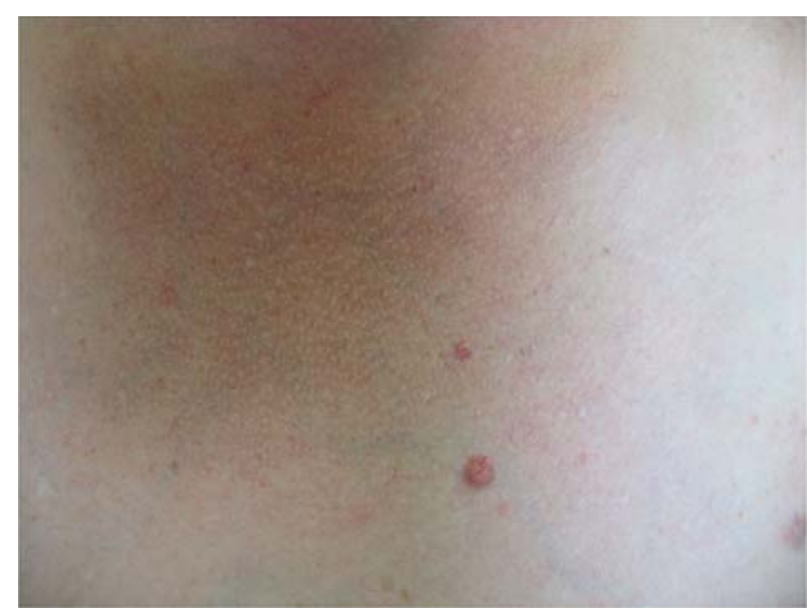

Figure 2. Nodular reddish lesions on the trunk

syndrome has been proposed (6). Up to now, more than 68 different mutations of CYLD gen have been identified $(7,8)$. The loss of this gene causes activation of NF-B which is a transcription factor with antiapoptotic activity (9).

Generally, benign multiple cylindromas may occasionally become malignant, particularly if present within BSS (10). In this study, we report on two cases of a very rare familial cylindromatosis in two sisters with multiple benign cylidromas with dermoscopic features of basal cell carcinoma.

\section{Case reports}

\section{Case 1}

A 43-year-old woman was referred to our Clinic with multiple painless nodular lesions, mainly distributed

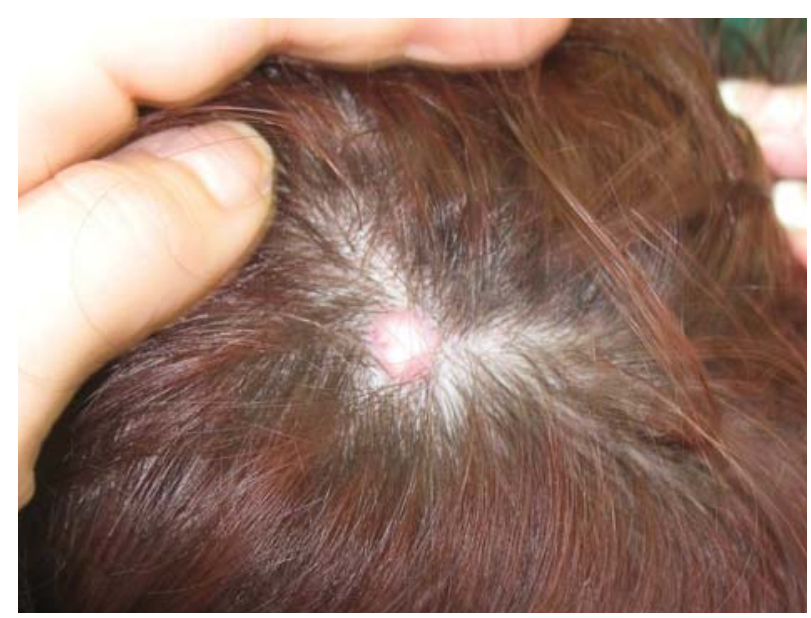

Figure 3. Nonpigmented nodular lesion on the scalp 


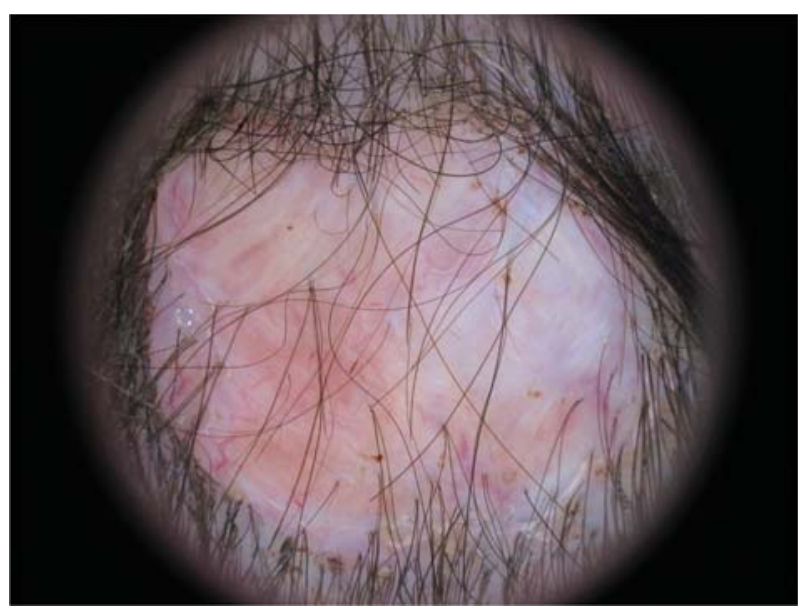

Figure 4. Dermoscopy of a nodular lesion on the scalp revealed pinkish coloration and a discrete vascular pattern

on the scalp and face, although sporadic lesions were also noticed on the trunk. The first lesion appeared at the age of 38 on the scalp, and their number increased over the following years. Clinically, all lesions were dome shaped, reddish nodules of different size (from $3 \mathrm{~mm}$ to $3 \mathrm{~cm}$ ) located mainly on the head and scalp and sporadically on the trunk (Figures 1 and 2). Dermoscopy showed absence of pigmented network and presence of white-ivory background with visible discrete polymorphous vessels (Figures 3 and 4). Several lesions were excised and histopathological

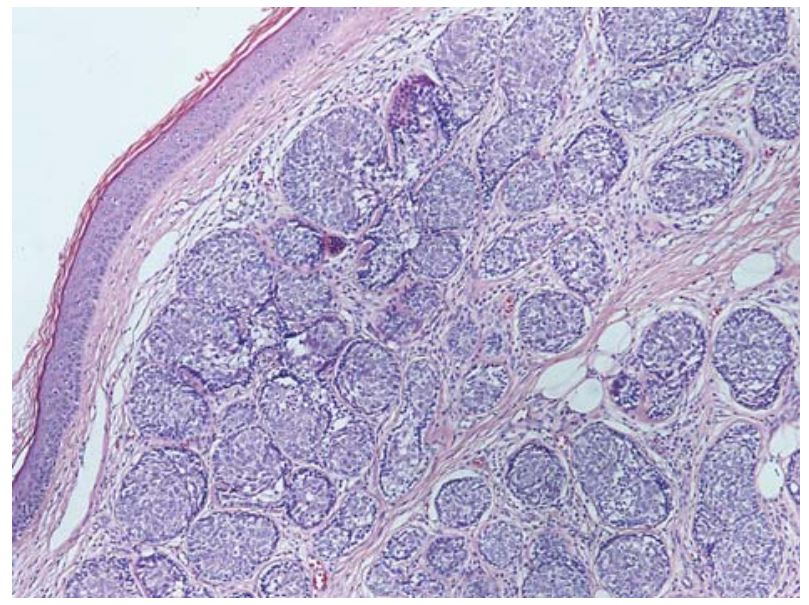

Figure 5. Non-encapsulated tumor arising from the dermis, forming irregular tumor islands, distributed in an aptly named "jigsaw" pattern. Surrounding the tumor islands, in discrete droplets within the nodules is a thick hyaline deposit analysis showed non-encapsulated nodules arising from the dermis, forming multiple irregular well defned cell islands, arranged in a jigsaw puzzle-like pattern, surrounded by an eosinophilic hyaline sheath, a pattern corresponding to diagnosis of cylindroma (Figure 5).

Due to possible association with other diseases, among other relevant analyses, ultrasound and computed tomography (CT) of parotid glands were performed, without any abnormalities detected.

\section{Case 2}

A 37-year-old woman, the sister of case 1, presented with multiple nonpigmented nodular lesions on the head and neck (Figures 6,7). The tumors were neither pruritic nor tender. Dermoscopy of lesions revealed arborizing vessels on a white-ivory or pinkish background, mimicking basal cell carcinoma (Figure 8). The arborizing vessels were more prominent at the periphery of lesions, while in some tumors blue dots and globules were also detected (Figure 9). Histopathological analysis of excised tumors corresponded to cylidromas (Figure 10). Ultrasound of parotid glands and CT were also performed with no abnormalities detected.

Both patients reported that their mother also had multiple tumors on her head.

After clinical evaluation of both cases, some lesions were recommended to be excised for esthetic reasons, due to rapid growth, or compression. Further follow-up was recommended.

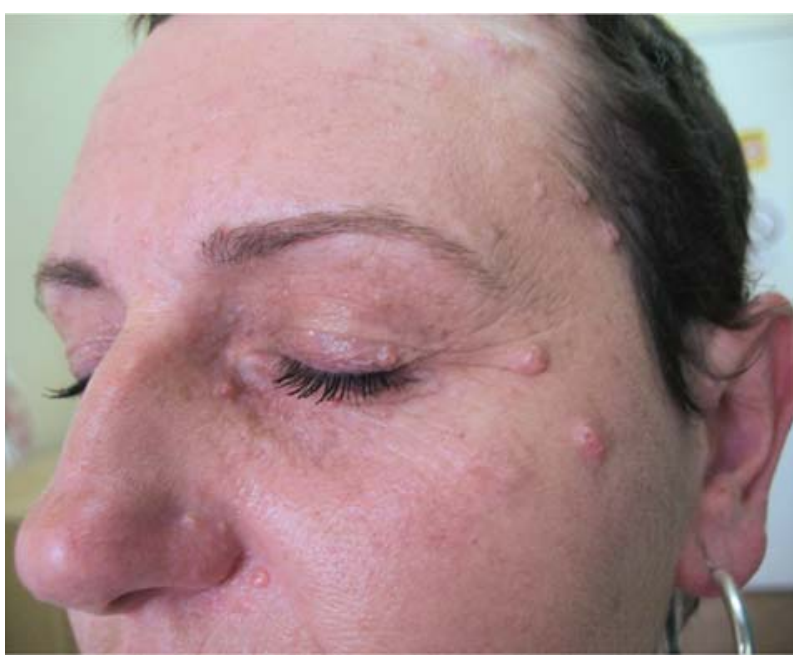

Figure 6. Multiple nonpigmented lesions on the face 


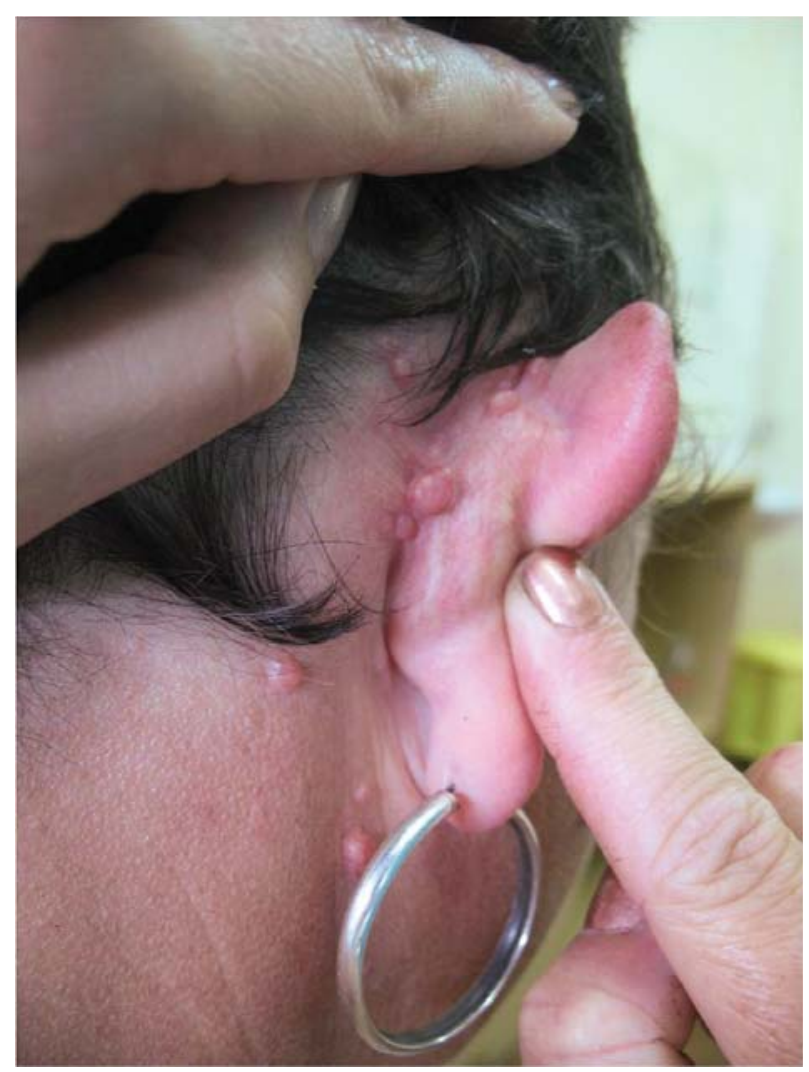

Figure 7. Pinkish lesions in the retroauricular region

\section{Discussion}

Though being classified upon morphological similarity to normal appendage structures, clinical appearance of adnexal tumors is usually non-specific. They are not diagnosed as such until after histopathological analysis. However, if the tumor shows ductal differentiation,

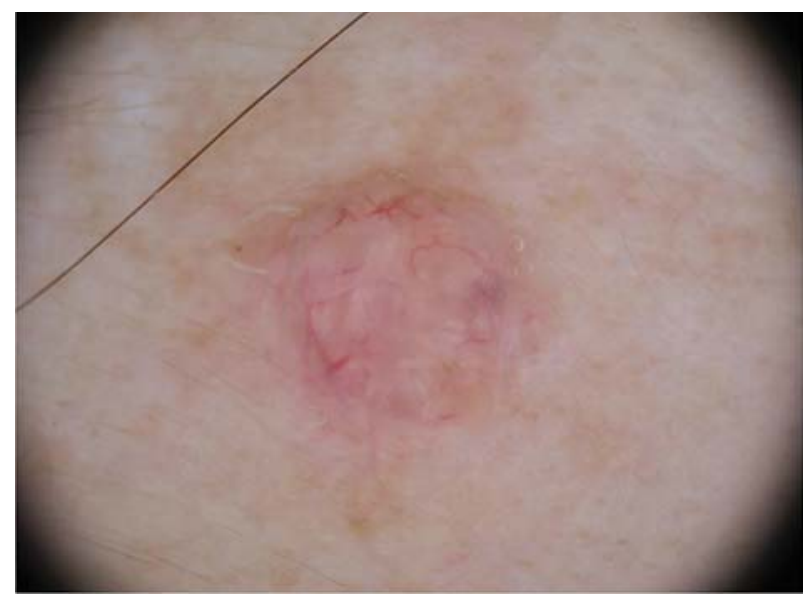

Figure 8. Dermoscopy revealed arborizing vessels at the periphery of the lesion

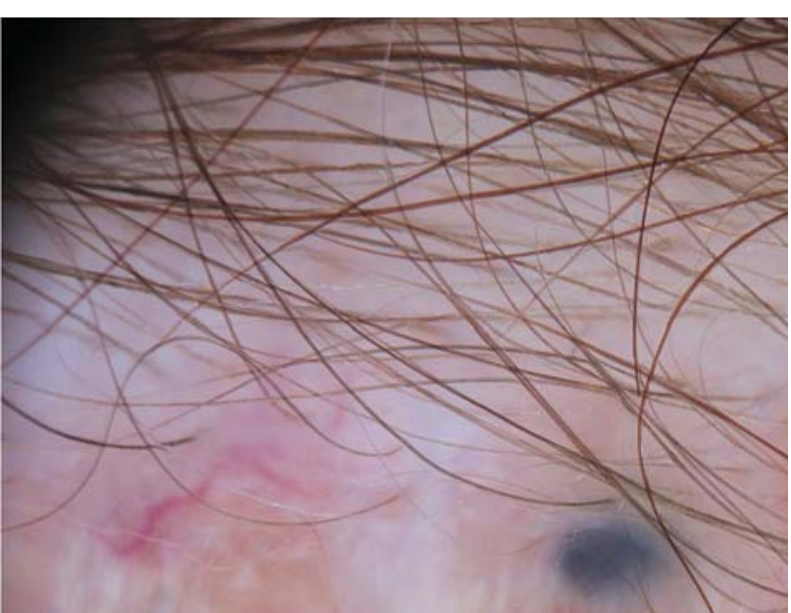

Figure 9. Blue globule on the whitish-pink background was detected by dermoscopy

it may be either eccrine or apocrine. Because there are no histochemical or immunohistochemical stains that allow distinction between eccrine and apocrine tumors, their differentitation is not possible, unless there is concomitant follicular appearance present. Therefore, tumors traditionally considered to be of eccrine differentiation, such as cylindroma, may show either line of differentiation, and this is probably most often apocrine (1). The aforementioned coexistence of multiple cylindromas with follicular tumors such as trichoepitheliomas, confirms apocrine line of differentiation at least in a certain number of these tumors. In some patients, there may be an admixture

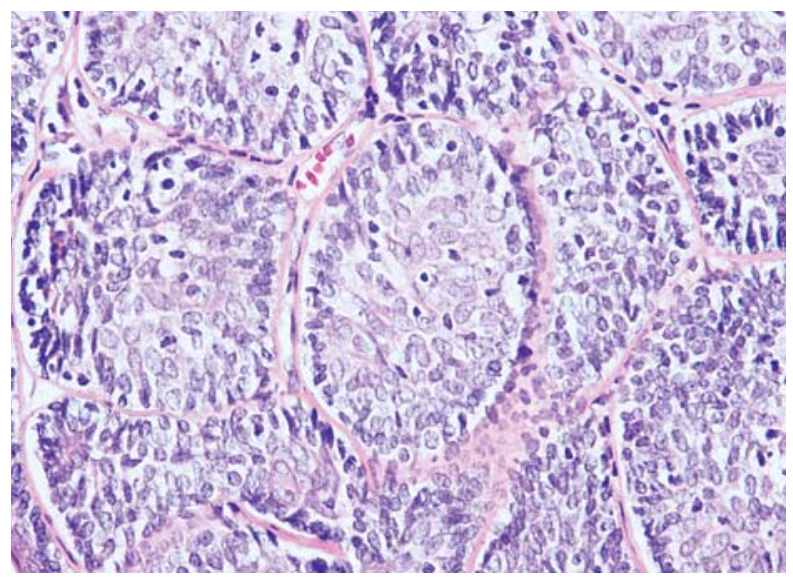

Figure 10. Two populations of cells are noted to make up the tumor nodules. A smaller cell with a hyperchromatic nucleus tending to the periphery, and larger cells with open nuclei throughout the centre of the nodule 
with trichoepithelioma, either in separate tumors or sometimes in the same tumor (1). Moreover, multiple trichoepitheliomas develop from undifferentiated germinative cells of the pilosebaceous - apocrine unit (11), which explains why in some cases they have features of spiradenoma and/or cylindroma, particularly in BSS (1).

Two sisters in our study were diagnosed based on tree conditions of the dominant tumor type, e.g. being cylindroma in familiar cyindromatosis (5). Clinical examination of all skin tumors showed that both sisters had similar tumor features, which corresponded to one tumor type, naimely cylidroma. The tumors were painless, different in size, with uniform dome shaped reddish appearance and typical localization. In both sisters dermoscopic examination of cylidromas revealed whitishpinkish background with discrete vascular pattern, and some arborizing telangiectasia. Although, arborizing vessels are dermoscopic features of basal cell carcinoma, this dermoscopic feature is also seen in cylidromas. Unlike in basal cell carcinomas, where arborizing vessels are more pronounced in the center, in case of cylindromas, vascular branches are more pronounced at the periphery. This observation may help in differentiation of basal cell carcinoma and cylindroma. There are currently only a few case reports on the dermoscopic features of cylindromas in the medical literature. The reported dermoscopic patterns of cylindromas include arborizing vessels on whitish-pinkish background, blue dots and globules, like in our cases. Without doubt, more studies are needed to establish the definite dermoscopic patterns of cylindromas.

Spiradenomas are often seen in conjunction with cylindromas in BSS, but they are rather painful, typically presenting with dermal nodules and blue/black appearance (2). Definitive diagnosis of cylindroma and spiradenoma requires histopathological analysis (5). Histopathologically, cylindromas exhibit a typical appearance composed of nests of basaloid cells arranged into mosaic-like masses (jigsaw-puzzle) in cross section resembling a cylinder (1).

This histopathological finding should raise the suspicion of a germline CYLD gen mutation in a young individual. In those with a mutation in CYLD gen, the penetrance in terms of tumor development is almost $100 \%$. Individuals with a family history, but without tumors, are at $50 \%$ risk of having a CYLD mutation. Genetic testing (unfortunately not available for us), allows individuals to assess their own risk as well as family planning. Testing can be performed using PCR for patients with: 1. multiple cylindromas, spiradenomas or trichoepitheliomas; 2. a single cylindroma, spiradenoma or trichoepithelioma and an affected first-degree relative with any of these tumors; 3. an asymptomatic family member at $50 \%$ risk with a known mutation in the family (5). More recently, the presence of dysregulated tropomyosin kinase (TRK) signalling, in patients with germline CYLD mutations, was detected and the treatment effficacy of lestaurtinib, a TRK inhibitor, was established in vitro (12). The morbidity associated with skin appendage tumors can be very high because the tumors are disfiguring, even causing sexual dysfunction. Different treatment choices available for adnexal tumors in BSS patients include excision of the tumor, dermabrasion, electrodesiccation, cryotherapy and radiotherapy using argon and C02 laser. There are proofs that aspirin and its derivatives can result in new adnexal lesions in these patients (13).

Although malignant transformation is very rare, there are reports of malignant transformation of dermal cylindromas and possibility of metastases to the lymph nodes, thyroid, liver, lungs and bones, causing hemorrhage and even meningitis (10). So far, less than 50 cases of cylindrocarcinomas have been reported in literature $(14,10)$. However, patients with BSS are not only prone for malignant transformation of their cylindromas, but also for developing benign or malignant tumors in tissues other than skin appendages, particularly of the salivary glands (15).

\section{Conclusion}

In this study we report two cases of a very rare familial cylindromatosis presenting as multiple benign cylidromas with dermoscopic features of basal cell carcinoma. All patients with multiple cylindromas in familial cylindromatosis should be counseled about increased risk for developing further tumors. Systemic and multidisciplinary approach with further follow up is always recommended.

\section{Abbreviations}

CYLD - cylindromatosis gene

NF-B - nuclear factor-B

BSS - Brooke-Spiegler syndrome 
CT - computed tomography

PCR - polymerase chain reaction

TRK - tropomyosin kinase

$\mathrm{CO}_{2}$ - carbon dioxide

\section{References}

1. Calonje E. Tumours of the skin appendages. In: Burns T, Breathnach S, Cox N, Griffiths C, editors. Rook's textbook of dermatology. $6^{\text {th }}$ ed. Oxford: Blackwell Publishing; 2010. p. 53.1-53.44.

2. Chen M, Liu H, Fu X, Yu Y, Yu G, Tian H, et al. Brooke-Spiegler syndrome associated with cylindroma, trichoepithelioma and eccrine spiradenoma. Int J Dermatol 2013;52(12):1602-4.

3. Hu G, Onder M, Gill M, Aksakal B, Oztas M, Gurer MA, et al. A novel missense mutation in CYLD in a family with BrookeSpiegler syndrome. J Invest Dermatol 2003;121:732-4.

4. Bowen S, Gill M, Lee DA, Fisher G, Geronemus RG, Vazquez $\mathrm{ME}$, et al. Mutations in the CYLD gene in Brooke-Spiegler syndrome, familial cylindromatosis, and multiple familial trichoepithelioma: lack of genotype-phenotype correlation. J Invest Dermatol 2005;124:919-20.

5. Dubois A, Wilson V, Bourn D, Rajan N. Genetic testing for Brooke-Spiegler syndrome, familial cylindromatosis and multiple familial trichoepitheliomas. PLoS Curr 2015;9(7).

6. Rajan N, Langtry JA, Ashworth A, Roberts C, Chapman P, Burn $\mathrm{J}$, et al. Tumor mapping in 2 large multigenerational families with CYLD mutations: Implications for disease management and tumor induction. Arch Dermatol 2009;145(11):1277-84.

7. Guardoli D, Argenziano G, Ponti G, Nasti S, Zalaudek I, Moscarella E, et al. A novel CYLD germline mutation in
Brooke-Spiegler syndrome. J Eur Acad Dermatol Venereol 2015;29(3):457-62.

8. Shiver M, Hughes M, Naylor M, McLarney B, Stolle C, Shalin S, Gao L. A novel CYLD gene mutation and multiple basal cell carcinomas in a patient with Brooke-Spiegler syndrome. Clin Exp Dermatol 2015 May 15. doi: 10.1111/ced.12669.

9. Brummelkamp TR, Nijman SM, Dirac AM, Bernards R. Loss of the cylindromatosis tumour suppressor inhibits apoptosis by activating NF-kappaB. Nature 2003;424(6950):797-801.

10. Borik L, Heller P, Shrivastava M, Kazlouskaya V. Malignant cylindroma in a patient with Brooke-Spiegler syndrome. Dermatol Pract Concept 2015;5(2):61-5.

11. Clarke J, Ioffreda M, Helm KF. Multiple familial trichoepitheliomas: a folliculosebaceous- apocrine genodermatosis. Am J Dermatopathol 2002;24:402-5.

12. Rajan N, Elliott R, Clewes O, Mackay A, Reis-Filho JS, Burn $\mathrm{J}$, et al. Dysregulated TRK signalling is a therapeutic target in CYLD defective tumours. Oncogene 2011;30(41):4243-60.

13. Oosterkamp HM, Neering H, Nijman SM, Dirac AM, Mooi WJ, Bernards R, et al. An evaluation of the efficacy of topical application of salicylic acid for the treatment of familial cylindromatosis. Br J Dermatol 2006;155:182-5.

14. Gerretsen AL, van der Putte SC, Deenstra W, van Vloten WA. Cutaneous cylindroma with malignant transformation. Cancer 1993;72(5):1618-23.

15. Malzone MG, Campanile AC, Losito NS, Longo F, Perri F, Caponigro F, et al. Brooke-Spiegler syndrome presenting multiple concurrent cutaneous and parotid gland neoplasms: cytologic findings on fine-needle sample and description of a novel mutation of the CYLD gene. Diagn Cytopathol 2015;43(8):654-8.

\section{Kliničke, histološke i dermoskopske karakteristike familijarne cilindromatoze - prikaz dva slučaja}

\section{Sažetak}

Uvod. Cilindromi predstavljaju benigne tumore adneksa kože, koji se lokalizuju pretežno na glavi ali mogu zahvatiti bilo koju drugu regiju kože sa folikulima dlake. Mutacije koje se javljaju u tumorsupresorskom genu na hromozomu 16q12-13, koji je nazvan cilindromatoza-CYLD gen, odgovorne su za njihov nastanak. Kada su prisutni u većem broju, npr. u familijarnoj cilindromatozi i Bruk-Špiglerovom (Brooke-Spiegler) sindromu, cilindromi se autozomno dominantno nasleđuju. Pored multiplih cilindroma i multiplih spiradenoma, u Bruk-Špiglerovom sindromu prisutni su i multipli spiradenomi.

$\mathrm{Na}$ osnovu rezultata genetskih ispitivanja i identifikacije u familijarnoj cilindromatozi, Bruk-Špiglerovom sindromu i u multiplom familijarnom trihoepiteliomu, heterozigotnih mutacija $\mathrm{u}$ istom CYLD genu, pretpostavlja se da ova tri različita oboljenja imaju istu genetsku osnovu te da se radi o tri fenotipske ekspresije jednog istog poremećaja. Dijagnoza se postavlja na osnovu prisustva dominantnog tumora, u familijarnoj cilindromatozi to je cilindrom, u multiplom familijarnom trihoepiteliomu je trihoepitelioma, dok je u Bruk-Špiglerovom sindromu prisutno nekoliko različitih adneksalnih tumora kože, uključujući cilindrome, spiradenome i trihoepiteliome. Pojava tumora je najčešća u ranom adultnom periodu života ali se mogu javiti i u detinjstvu i kasnije, uglavnom do četvrete decenije života.

Prikaz slučaja. U radu su prikazana dva slučaja familijarne pojave multiplih cilindroma na licu i 
poglavini kod dve rođene sestre, četrdesetogodišnje i tridesetsedmogodišnje ženske osobe, koje su u anamnezi obe navele da i njihova majka ima tumore po glavi. Klinički su sve lezije, kod obe sestre, imale uniformni izgled u formi ružičastih do crvenkastih jasno definisanih tumorskih formacija u vidu nodusa različite veličine, dijametra od $3 \mathrm{~mm}$ do $3 \mathrm{~cm}$, lokalizovanih na licu vratu i glavi i sporadično na trupu (slike 1, 2, 3, 6 i 7). Lezije nisu izazivale osećaj ni bola niti svraba. Dermoskopskom analizom lezija u oba slučaja, uočeni su arborizovani krvni sudovi na beloj, boje slonovače ili ružičastoj osnovi (slike 4 i 8). Arborizovani krvni sudovi su bili uočljiviji na periferiji, u nekim tumorima detektovane su plave tačke i globule (Slika 9), nalaz koji se može videti i u bazocelularnom karcinomu. Histopatološkom analizom utvrđeno je prisustvo neinkapsulisanih nodusnih formacija dermalnog ishodišta, formiranih od većeg broja nepravilnih ćelijskih ostrvaca, jasno ograničenih i međusobno razdvojenih eozinofilnim hijalinskim depozitom u vidu membrane - nalaz koji je odgovarao histološkim osobinama cilindroma (slike 5, 10).

Diskusija. Dijagnoza je kod obe sestre postavljena na osnovu stava da se dijagnoza sva tri oboljenja zasniva na dominantnom tumoru, npr. to je cilindrom u familijarnoj cilindromatozi. Kod obe sestre, sve promene su imale klinički izgled koji je bio kompatibilan sa onim u cilindromu. Iako su arborizovani krvni sudovi u dermoskopskom nalazu karakteristika bazocelularnog karcinoma, mogu se videti i u drugim promenama, npr. cilindromu. $\mathrm{Za}$ razliku od bazocelularnog karcinoma kod koga su arborizovani krvni sudovi jače izraženi u centru lezija, u cilindromu vaskularni elementi su naglašeni periferno, što olakšava postavljanje diferencijalne dijagnoze. Dermoskopske osobine cilindroma nisu dovoljno dobro definisane zbog malog broja objavljenih radova. Pored arborizovanih krvnih sudova na bledoružičastoj osnovi, u dermoskopskom nalazu cilindroma opisane su i plave tačke i globule, takođe dermoskopske karakteristike bazocelularnog karcinoma.

Spiradenomi se često javljaju udruženo sa cilindromima kao što je to u Bruk-Špiglerovom sindromu, ali se od njih razlikuju klinički karakterističnom plavo-crvenom prebojenošću i bolni su. Za postavljanje definitivne dijagnoze cilindroma i spiradenoma neophodna je patohistološka analiza, s obzirom na tipični nalaz u cilindromu za koji su karakteristična gnezda bazaloidnih ćelija organizovana u vidu mozaika, koji na poprečnim presecima podsećaju na cilindre.

Patohistološki nalaz koji ukazuje na cilindrom treba kod mlade osobe da pobudi sumnju na prisustvo mutacije u CYLD genu. Kod osoba koje poseduju mutaciju na CYLD genu, penetracija u smislu pojave tumora je skoro $100 \%$. Kod osoba koje imaju obolele srodnike, a sami nemaju promene, rizik da imaju CYLD mutacije iznosi 50\%. Genetsko testiranje (nama nažalost nije bilo dostupno), omogućuje određivanje postojanja rizika i planiranje porodice. Teba ga sprovoditi pomoću PCR tehnike u slučaju postojanja: 1. multiplih cilndroma, spiradenoma ili trihoepitelioma; 2 . pojedinačnog cilindroma, spiradenoma ili trihoepitelioma i obolelog srodnika prvog reda sa bilo kojim od navedenih tumora; 3. člana porodice bez simptoma sa $50 \%$ rizikom i postojanjem mutacije u porodici. Nedavno je kod osoba koje imaju mutaciju na CYLD genu utvrđena disregulacija tropomiozin kinaznog signalnog puta, posle čega je usledilo ispitivanje čiji rezulatati su potvrdili terapijsku efikasnost flestauriniba inhibitora tropomiozin kinaze in vitro.

Stopa morbiditeta kod osoba sa adneksalinim tumorima je visoka s obzirom na estetski aspekt koji u pojedinim slučajevima može izazvati seksualnu disfunkciju i ozbiljno narušiti kvalitet života obolelog! Terapija podrazumeva brojne modalitete: totalna hirurška ekscizija, dermoabrazija, elektrodisekacija, krioterapija, argonski i CO2 laser. Postoje dokazi da aspirin i njegovi derivati izazivaju pojavu novih promena a pokušaji lečenja lokalnom primenom salicilne kiseline nisu dali zadovoljavajuće rezultate.

Iako je maligna transformacija veoma retka, postoje objavljeni slučajevi metastaziranja maligno transformisanog dermalnog cilindroma u limfne čvorove, štitastu žlezdu, jetru, pluća i kosti, sa pojavom meningitisa i krvarenja. Do sada je u svetskoj literaturi objavljeno oko 50 slučajeva cilindrokarcinoma. Osobe sa Bruk-Špiglerovim sindromom ne samo da poseduju veći rizik za malignu alteraciju cilindroma, nego i za pojavu benignih ili malignih tumora $u$ drugim tkivima, naročito u pljuvačnim žlezdama.

Zaključak. U ovom radu je prikazan veoma redak slučaj familijarne cilindromatoze sa multiplim benignim cilindromima koji su imali dermoskopske 
karakteristike bazocelularnog karcinoma. Svim osobama koje imaju familijarnu cilindromatozu treba predočiti da imaju povišeni rizik za nastanak novih tumora. Sistemski i multidisciplinarni pristup uz redovno praćenje obolelog predstavlja osnovni postulat.

\section{Ključne reči}

Multiple primarne neoplazme; Dermoskopija; Tumori kože; Skalp; Hereditarni neoplastični sindromi; Prikazi slučajeva; Mutacija; Histološke tehnike 